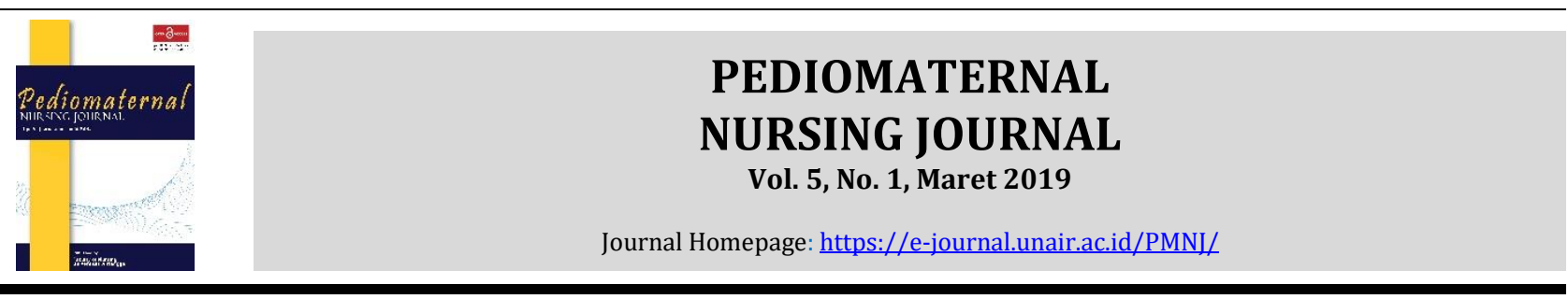

Original Research

\title{
Analisis Faktor Perilaku Seks Pranikah Remaja Berdasarkan Teori Transcultural Nursing di Kabupaten Sumba Timur
}

\section{(Analysis of Adolescent Premarital Sex Behavior Factors Based on Transcultural Nursing Theory in East Sumba)}

\author{
Imelda Mbati Mbana, Esty Yunitasari, dan Ni Ketut Alit Armini \\ Fakultas Keperawatan, Universitas Airlangga, Surabaya, Jawa Timur, Indonesia
}

\author{
ARTICLE HISTORY \\ Received: May 12, 2019 \\ Accepted: May 24, 2019

\section{KEYWORDS} \\ premarital sex behavior; sex \\ education; transcultural nursing

\section{CORRESPONDING AUTHOR} \\ Imelda Mbati Mbana \\ imelda.mbati.mbana - \\ 2017@fkp.unair.ac.id \\ Fakultas Keperawatan, \\ Universitas Airlangga, Surabaya, \\ Jawa Timur, Indonesia
}

\begin{abstract}
Introduction: Adolescent sex behavior is strongly influenced by several things related to the theory of transcultural nursing. The high teenage sex behavior has an impact on the high rate of unwanted pregnancies, maternal mortality and infant mortality and various other health problems. This study aims to analyze transcultural nursing factors related to premarital sexual behavior of adolescents in East Sumba Regency.

Methods: The design of this study is descriptive analytical with a cross-sectional approach. The sample was selected by simple random sampling, namely students of class X and XI SMA N 1 Lewa and SMA N 1Nggaha Ori Angu. Data retrieval using questionnaire instruments as many as 6 instruments that have been tested for validity and reliability by researchers and the results of the study were analyzed using the chi square-Pearson test.

Results: The high rate of premarital sexual behavior of adolescents in East Sumba Regency was related to social factors and kinship ( $p=0.004)$, culture and lifestyle $(p=0.011)$, and economy $(p=0.004)$. Premarital sex behavior is not related to technological factors $(p=$ $0.292)$, policy and regulations $(p=0.775)$ and education factors $(p=0.890)$.

Conclusion: There was 3 variables related to premarital sex, namely social factors and kinship, culture and lifestyle and economy. This is due to the existence of local cultural customs and customs which allow arranged marriage in adolescents. Matchmaking is carried out by parents with the aim of completing the social strata (maramba) and mostly to improve the economic status of the family.
\end{abstract}

Mbana, I. M., Yunitasari, E., \& Armini, N. K. A. (2019). Analisis Faktor Perilaku Seks Pranikah Remaja Berdasarkan Teori Transcultural Nursing di Kabupaten Sumba Timur. Pediomaternal Nurs. J., 5(1), 124-131.

\section{PENDAHULUAN}

Masa remaja merupakan periode terjadinya pertumbuhan dan perkembangan yang pesat baik secara fisik, psikologis maupun intelektual, serta memiliki rasa keingintahuan yang besar, menyukai petualangan dan tantangan serta cenderung berani menanggung risiko atas perbuatannya tanpa didahului oleh pertimbangan yang matang. (Luh, 2013). Remaja melakukan hubungan seks pranikah sebagian besar karena penasaran/ingin tahu atau terjadi begitu saja dan dipaksa oleh pasangan. (SDKI, 2012). Kurangnya pemahaman remaja tentang hidup sehat, resiko hubungan seksual dan kemampuan untuk menolak hubungan yang tidak diinginkan menjadi alasan perilaku seks pranikah (2). Faktor lain yang diduga turut berkontribusi adalah faktor budaya, efikasi dan pengetahuan orang tua, serta kondisi individual remaja dijadikan alasan bertidak tanpa kompromi dan memilih mengikuti tren atau kebiasaan teman sebaya (3).

Perilaku seks pranikah remaja dan alasannya perlu dikaji melalui fenomena dan analisis konseptual yang merupakan bagian dari moral, kepatuhan dan konsep etika (4). Beberapa daerah di Indonesia sangat erat kaitannya antara perilaku seks pranikah 
dengan aspek budaya, ekonomi, dukungan keluarga dan teknologi. Beberapa budaya yang ada di Indonesia cenderung permisif terhadap gaya pacaran remaja (5).

Sumba Timur memiliki adat dan budaya pernikahan yang menganut perkawinan satu arah atau eksogami. Model pernikahan yang berlaku adalah perjodohan antara anak laki-laki dari garis ibu dijodohkan dengan anak perempuan dari garis bapak. Anak tidak langsung dinikahkan, tapi diikat secara adat oleh kedua keluarga besar sebagai tanda sahnya perjodohan (6). Rata-rata remaja yang melakukan perilaku seks pranikah adalah yang dijodohkan, selain merasa sudah sah secara adat, ada juga yang tidak setuju dengan perjodohan tersebut dan melakukan perilaku seks pranikah dengan laki-laki yang dicintainya dan melakukan perkawinan lari (7). Transcultural nursing, menjelaskan ada beberapa aspek kehidupan yang dapat menyebabkan manusia berperilaku, seperti perbedaan nilai-nilai budaya, suku, religious sosial, ekonomi, pendidikan dan demografi (8). Remaja perlu menjaga perilaku seksual secara sehat adalah karena dalam perkembangannya, belum memahami tentang dampak perilaku seksual yang beresiko, apalagi rasa keingintahuan remaja mengenai seksual tinggi (9).

Provinsi Nusa Tenggara Timur mencatat, sebanyak 31 \% remaja di Kota Kupang sudah pernah melakukan hubungan seks, dan 18,8 \% kasus HIV/AIDS di kota kupang terjadi pada remaja berusia 15-24 tahun, 318 kasus IMS pada usia 11-24 tahun. Angka ini turun dari angka pada tahun sebelumnya Dinas KB setempat mencatat ada 558 perempuan hamil dibawah usia subur. Berdasarkan wawancara dengan kepala seksi Pelayanan Kesehatan Peduli Remaja (PKPR) di Kabupaten Sumba Timur didapatkan data jumlah remaja yang hamil pada usia sekolah tercatat sebanyak 17 orang di Kecamatan Nggaha Ori Angu. Angka ini meningkat dari tahun sebelumnya yaitu 11 orang, beberapa diantaranya adalah karena perjodohan orang tua dan perkawinan lari.

Berbagai penyebab internal maupun eksternal menjadi pemicu perilaku seks pranikah pada remaja. Selain itu penyebab eksternal lain adalah remaja mengalami pencabulan atau pelecehan secara seksual pada masa kecilnya. (10). Beberapa penyebab eksternal yang terjadi adalah dampak dari penyebab internal dalam diri remaja yang menyebabkan remaja melakukan perilaku seksual yang tidak sehat, sikap permisif, kurangnya kontrol diri, tidak bisa mengambil keputusan mengenai kehidupan seksual yang sehat atau tidak bisa bersikap asertif terhadap ajakan teman, pengaruh teknologi dan penggunaan internet yang salah juga sangat menunjang perilaku seks pranikah pada remaja (11).

Motivasi dalam pola perkawinan budaya Sumba tidak hanya bertujuan untuk melanjutkan hubungan kekerabatan, melainkan sering digunakan untuk keperluan lainnya seperti melunasi hutang orang tua, anak gadis dari keluarga yang berhutang akan melakukan pernikahan dengan anak laki-laki dari pemberi hutang, hal ini dilakukan tanpa diketahui oleh gadis, dan dilaksanakan saat anak dianggap sudah bisa menghasilkan keturunan atau sudah menstruasi (6). Konflik-konflik yang terjadi dalam kehidupan remaja menjadi kompleks dan biasanya keputusan yang diambil dalam menghadapi konflik tersebut tidak tepat, mereka akan jatuh ke dalam perilaku berisiko dan remaja harus menanggung akibat jangka pendek dan jangka panjang dalam berbagai masalah yang dihadapinya (12). Dampak negatif yang terjadi pada remaja sebagai akibat dari perilaku seksual sebelum menikah pada remaja adalah kehamilan yang tidak diinginkan (KTD) atau kehamilan yang terjadi sebelum menikah, kehamilan beresiko, angka kematian ibu dan angka kematian bayi meningkat. serta tingginya angka kehamilan remaja usia 15-19 tahun mencapai 48 dari 1000 kehamilan menunjukkan ada 1,7 juta remaja berusia dibawah 24 tahun yang melahirkan setiap tahun (13). Perilaku seks pranikah berhubungan erat dengan budaya, dukungan keluarga, ekonomi dan teknologi (14).

Pemerintah telah melakukan beberapa cara untuk mengatasi berbagai permasalahan remaja, diantaranya dengan pencanangan program pelayanan kesehatan peduli remaja (PKPR) yang bertujuan meningkatkan pelayanan kesehatan remaja berkualitas, meningkatkan pemanfaatan Puskesmas oleh remaja, untuk mendapatkan pelayanan kesehatan dan informasi, dan meningkatkan pengetahuan remaja dalam pencegahan masalah kesehatan yang melibatkan seluruh remaja di wilayah kerja Puskesmas, baik remaja sudah menikah dan remaja belum menikah (Kementrian Kesehatan Republik Indonesia 2014). Adanya perhatian pemerintah dan dukungan orang tua dapat menguragi resiko perilaku seks pranikah pada remaja. (16).

Transcultural Nursing menekankan pemahaman yang benar pada diri perawat terhadap budaya klien, individu, kelompok maupun masyarakat sehingga dapat mencegah terjadinya culture shock maupun cultur imposition. Perawat dituntut harus mempunyai pengetahuan mengenai pandangan dunia tentang dimensi dan budaya serta struktur sosial yang berkembang di masyarakat (16). Perawat bertugas menjembatani sistem perawatan yang dilakukan masyarakat awam dengan sistem perawatan profesional melalui asuhan keperawatan serta mampu membuat keputusan dan rencana tindakan keperawatan yang diberikan kepada remaja dalam hubungannya dengan permasalahan perilaku seks pranikah remaja dengan tidak serta merta merubah kebudayaan atau adat istiadat yang berlaku di masyarakat, melainkan sedikit memodifikasi untuk memperbaiki perilaku seks pranikah remaja yang berdampak buruk pada kehidupan dan masa depan remaja (17).

Perilaku seks pranikah remaja dan alasannya perlu dikaji melalui fenomena dan analisis konseptual yang merupakan bagian dari moral, kepatuhan dan konsep etika (4). Beberapa daerah di Indonesia 
sangat erat kaitannya antara perilaku seks pranikah dengan aspek budaya, ekonomi, dukungan keluarga dan teknologi. Beberapa budaya yang ada di Indonesia cenderung permisif terhadap gaya pacaran remaja (5).

\section{METODE}

\subsection{Desain}

Penelitian ini menggunakan desain penelitian deskriptif analitik dengan pendekatan cross-sectional

\subsection{Populasi, sampel, dan sampling}

Populasi target dalam penelitian ini adalah Seluruh siswa SMA N 1 Nggaha Ori Angu dan SMA N 1 Lewa kelas X dan XI yang berjumlah 865 orang. Populasi terjangkau dalam penelitian ini adalah seluruh siswa SMA N 1 Nggaha Ori Angu dan SMA N 1 Lewa kelas X dan XI yang memenuhi kriteria inklusi yaitu, yang hadir dalam proses pengambilan data dan lolos dalam proses simple random sampling. Responden yang dianggap lolos adalah resonden yang mendapat undian atau lotre bertanda khusus yang dibagikan kepada 865 siswa.

\subsection{Variabel}

Variabel independen dalam penelitian ini adalah faktor teknologi, sosisal dan kekerabatan, budaya dan gaya hidup, kebijakan dan peraturan yang berlaku, ekonomi dan pengetahuan. Variabel dependen dalam penelitian ini adalah perilaku seks pranikah remaja.

\subsection{Instrumen}

Instrumen penelitian ini adalah hasil modifikasi berdasarkan kuesioner penelitian (18). Kuesioner data demografi merupakan kuesioner untuk mengetahui secara umum data responden, berisi 8 pertanyaan meliputi nomor responden, alamat, asal sekolah, kelas, jenis kelamin, usia, agama dan suku.

Kuesioner tentang faktor teknologi dibuat berdasarkan defenisi operasional yang mengacu pada defenisi dari faktor teknologi pada teori transcultural nursing. Kuesioner ini berisi 12 pertanyaan dengan menggunakan close ended questtion dengan jawaban ya dan tidak. Jika responden menjawab ya $>50 \%$ pertanyaan berarti responden memanfaatkan teknologi yang ada. Jika responden menjawab tidak $<50 \%$ pertanyaan berarti responden tidak memanfaatkan teknologi yang ada. Hasil pengukuran dikategorikan dalam skala nominal dengan skoring ya:1 dan tidak:2.

Kuesioner faktor sosial dan kekerabatan terhadap responden meliputi dukungan emosional, dukungan informasi,dukungan fisik dan dukungan penghargaan. Kuesioner terdiri dari pilihan jawaban ya dan tidak, Jika responden menjawab ya $>50 \%$ berarti responden memiliki dukungan sosial dan kekerabatan yang baik. Jika responden menjawab tidak $<50$ berarti responden tidak memiliki dukungan sosial dan kekerabatan. Kuesioner menggunakan Close ended question dengan skoring ya:2 dan tidak: 1 untuk pertanyaan favorable dan ya:1, tidak:2 untuk pertanyaan unfavorable.

Kuesioner nilai budaya dan gaya hidup dengan pilihan jawaban ya, dan tidak Terdiri dari 8 pertanyaan, pernyataan 1,2,3,4,5 dan 6 merupakan pernyataan favorable, pernyataan 7 dan 8 merupakan pernyataan unfavorable. Jika responden menjawab ya $>50 \%$ berarti responden mengikuti budaya. Jika responden menjawab tidak $<50 \%$ berarti responden tidak mengikuti budaya dengan skoring ya:2 dan tidak:1 untuk pertanyaan favorable dan ya:1, tidak:2 untuk pertanyaan unfavorable Pertanyaan favorable2:Ya 1:Tidak Pertanyaan unfavorable 1:ya 2:tidak

Kuesioner faktor kebijakan dan peraturan yang berlakudengan pilihan jawaban sangat setuju, setuju, tidak setuju, sangat tidak setuju. Terdiri dari 5 pertanyaan, pernyataan 1,2,3 merupakan pernyataan favorable, pernyataan 4 dan 5 merupakan pernyataan unfavorable dengan skoring ya:2 dan tidak:1 untuk pertanyaan favorable dan ya:1, tidak: 2 untuk pertanyaan unfavorable. Pertanyaan Favorable 2:ya 1:tidak pertanyaan Unfavorable 1:ya 2:tidak

Kuesioner faktor ekonomi diberikan pertanyaan sangat setuju, setuju, tidak setuju, sangat tidak setuju. Terdiri dari 5 pertanyaan, pernyataan 1,2,3 merupakan pernyataan favorable, pernyataan 4 dan 5 merupakan pernyataan unfavorable dengan skoring pertanyaan favorable 1: sangat tidak setuju 2:tidak setuju 3:setuju 4 : sangat setuju pernyataan unfavorable 4:sangat tidak setuju 3:tidak setuju, 2:setuju 1:sangat setuju.

Kuesioner faktor Pengetahuan dengan pilihan jawaban sangat setuju, setuju, tidak setuju, sangat tidak setuju. Terdiri dari 5 pertanyaan, pernyataan 1,2,4 merupakan pernyataan favorable, pernyataan 3 dan 5 merupakan pernyataan unfavorable dengan skoring Ya:2 Tidak:1

\subsection{Prosedur}

Peneliti melakukan Pengambilan data pada tanggal 3 Desember 2018 di SMA N 1 Lewa dan tanggal 5 Desember di SMA N 1 Nggaha Ori Angu. Pengambilan data dibantu oleh Badan Kesatuan Bangsa dan Politik desa setempat yang direkomendasikan oleh Bakesbangpol Kabupaten Sumba Timur dan dibantu oleh Wakil Kepala Sekolah dan Guru BK. Sebelum peneliti membagikan kuesioner, siswa di kumpulkan dalam sebuah aula dan menentukan responden dengan cara membagikan lotre kepada seluruh Siswa kelas X dan XI yang hadir pada saat pengambilan data. Responden terpilih menempati ruang aula untuk proses pengambilan data, responden tidak terpilih dipersilahkan untuk meninggalkan ruangan aula. Sebelum membagikan kuesioner kepada siswa terpilih, peneliti memberikan beberapa penjelasan tentang tujuan penelitian, jaminan kerahasiaan, dan pengisian lembar persetujuan responden.

Pelaksanaan pengambilan data responden mengisi data demografi terlebih dahulu dan selanjutnya mengisi pertanyaan-pertanyaan yang sudah disediakan. Waktu yang diperlukan untuk 
mengisi kuesioner adalah sekitar 1 jam. Setelah pengisian peneliti memeriksa kelengkapan jawaban dan peneliti membagikan souvenir berupa alat tulis sebagai tanda terimakasih. Selama proses pengambilan data, peneliti dibantu oleh 1 asisten peneliti yaitu mahasiswa Fakultas Ilmu Keguruan dan Pendidikan Universitas Nusa Cendana yang sebelumnya sudah diberi arahan oleh peneliti dalam proses pengambilan data.

\subsection{Analisis}

Penelitian ini dilakukan analisis dengan IBM SPSS statistic 25 dengan uji korelari pearson rho dengan signifikansi $5 \%$.

\subsection{Ethical Clearance}

Penelitian ini dinyatakan lolos kaji etik dan mendapatkan sertifikat ethical approval dengan No.sertifikat nomor 1192-KEPK yang dikeluarkan oleh Komite Etik Penelitian Kesehatan Fakultas Keperawatan Universitas Airlangga tanggal 28 November 2018.

\section{Hasil}

Karakteristik demografi responden, menunjukkan bahwa rata-rata siswa kelas X dan kelas XI sebagian besar berusia diantara 15-16 tahun sebanyak 140 siswa, diikuti dengan yang berusia $>17$ tahun sebanyak 124 siswa, dan sisanya $<15$ tahun sebanyak 9 orang. Pada kategori jenis kelamin, data menunjukkan sebagian besar siswa kelas X dan kelas XI adalah perempuan, dengan 209 siswa dan laki-laki dengan 64 siswa. Pada kategori agama, rata-rata siswa/i kelas X ddan XI adalah beragama Kristen Protestan sebanyak 190 siswa, 30 siswa untuk yang beragama Katholik, 38 siswa/ yang masih menganut aliran kepercayaan marapu dan 15 siswa yang beragama Islam. Pada kategori suku, rata-rata siswa/i di SMA N 1 Lewa dan SMA N 1 Nggaha Ori Angu adalah suku Sumba Timur asli yang berjumlah 201 orang, diikuti berbagai suku lain diantaranya Sabu, Bima, Sabu, Rote, Timor dan beberapa suku lain yang ada di Indonesia sebanyak 31 siswa, berikutnya suku sumba barat sebanyak 21 orang, Sumba Barat Daya yang berjumlah 10 orang dan suku Sumba Tengah yang berjumlah 4 orang. Banyaknya siswa yang berasal dari berbagai suku di dua kecamatan tersebut karena hubungan kawin mawin dan faktor ekonomi. Ratarata pedagang sembako dan pelaku bisnis di Kabupaten Sumba Timur berasal dari daerah Jawa, Bima dan daerah lain di luar Sumba [Tabel 1].

Tidak ada hubungan antara perilaku seks pranikah dengan paparan media. Hal ini ditunjukkan dari uji hubungan pearson chi-square diperoleh bahwa sebagian besar siswa/i tidak terpapar media memiliki resiko perilaku seks panikah, dibandingkan dengan yang terpapar media informasi. dari 222 siswa yang memiliki perilaku seks pranikah menyimpang, 197 diantaranya tidak terpapar media/teknologi. Rata-rata sumber informasi yang diperoleh tentang perilaku seks pranikah berasal dari teman dekat sebanyak 147 (56\%) dibanding dengan informasi dari petugas kesehatan.

Hasil dari tabel 2 menunjukkan hasil analisis faktor perilaku seks pranikah, bahwa sebagian besar remaja tidak mendapat dukungan sosial dan kekerabatan dari keluarga dalam hubungannya dengan perilaku seks pranikah yang menyimpang. Dari 273 responden diperoleh hasil sebanyak 177 (65\%) responden yang tidak memiliki dukungan sosial dan kekerabatan. hal ini disebabkan karena rata-rata responden tidak tinggal serumah dengan orang tua mereka, melainkan tinggal dengan famili lain seperti nenek, paman/bibi, bahkan tinggal dengan kenalan dari orang tua yang tidak memiliki hubungan kekerabatan sama sekali dengan responden. Berdasarkan hasil uji korelasi pearson dengan $p=0,004<0,05$ artinya Ho diterima. Hasil statistik menunjukkan bahwa ada hubungan antara faktor sosial dan kekerabatan dengan perilaku seks pranikah remaja di Kabupaten Sumba Timur.

Sebagian besar responden dengan perilaku seks menyimpang memiliki nilai budaya yang negatif dalam arti menganggap budaya atau tradisi perjodohan adalah biasa atau menerima adat istiadat dan perjodohan. Hal ini terlihat dari 222 responden yang berperilaku seks pranikah menyimpang 173 menganggap biasa (mengkuti budaya) melakukan seks sebelum menikah karena tradisi perjodohan, dan dari 51 responden yang berperilaku seks pranikah tidak menyimpang hanya terdapat 20 responden yang tidak mengikuti budaya. Berdasarkan hasil uji korelasi pearson dengan $\mathrm{p}=0,011<0,05$ dengan arti Ho diterima ada hubungan yang signifikan antara budaya dan gaya hidup dan perilaku seks pranikah remaja. Hasil statistik menunjukkan bahwa ada hubungan antara faktor budaya dan gaya hidup dengan perilaku seks pranikah remaja di Kabupaten Sumba Timur.

Nilai korelasi pearson chi-square untuk variabel kebijakan dan peraturan yang berlaku adalah $\mathrm{p}=0,775>0,05$ dengan arti Ho ditolak, tidak ada hubungan yang signifikan antara kebijakan dan praturan yang berlaku dengan perilaku seks pranikah remaja. Ini terlihat dari 222 responden yang berperilaku seks pra nikah menyimpang terdapat 211 responden merasa tidak perlu adanya dukungan kebijakan dan peraturan dan 11 responden yang memerlukan dukungan kebijakan dan peraturan. Sedangkan dari 51 responden yang menerima seks pra nikah terdapat 2 responden tidak memerlukan dukungan kebijakan dan peraturan dan 49responden memerlukan adanya dukungan kebijakan dan peraturan.

Sebagian besar remaja berperilaku seks menyimpang 177 diantaranya memiliki ekonomi yang buruk dan 45 responden berasal dari keluarga dengan ekonomi baik, dari 51 remaja dengan perilaku seks pranikah tidak menyimpang 20 remaja berasal dari keluarga dengan ekonomi baik dan 31 dari keluarga dengan ekonomi kurang. Berdasarkan output di atas didapatkan nilai korelasi pearson chisquare sebesar 1.494 dengan nilai signifikansi 
sebesar $0.004<0.05$, maka dapat diambil kesimpulan bahwa terdapat hubungan signifikan antara ekonomi dengan perilaku seks pra nikah remaja di Kabupaten Sumba Timur.

Nilai korelasi pearson chi-square untuk variabel ahuan diatas diketahui bahwa dari 222 responden yang memiliki seks pra nikah menyimpang terdapat 89 reponden dengan pengetahuan cukup dan 132 responden dengan pengetahuan kurang. Sedangkan seks pranikah remaja dapat terjadi, seperti yang dikatakan (19) pemanfaatan teknologi dapat dipengaruhi oleh peminatan individu itu sendiri (16).

Sesuai penelitian yang menyatakan bahwa tidak terdapat hubungan anatara faktor teknologi dengan perilaku seks pranikah remaja. Aspek norma dan moral adalah hal yang paling tinggi pengaruhnya dengan angka perilku seks pranikah remaja, bukan teknologi. Remaja dengan norma dan moral baik,

Tabel 1. Distribusi Karakteristik Responden Analisi Faktor Perilaku Seks Pranikah Remaja Berbasis Transcultural Nursing $(\mathrm{n}=273)$

\begin{tabular}{|c|c|c|c|}
\hline Karakteristik Responden & Kategori & $\mathbf{n}$ & $\%$ \\
\hline \multirow{2}{*}{ Jenis Kelamin } & Laki-laki & 64 & 24 \\
\hline & Perempuan & 209 & 76 \\
\hline \multirow[t]{3}{*}{ Usia } & 12-14 Tahun & 9 & 3 \\
\hline & 15-16 Tahun & 140 & 51 \\
\hline & >17 Tahun & 124 & 46 \\
\hline \multirow[t]{4}{*}{ Agama/Aliran Kepercayaan } & Katholik & 30 & 11 \\
\hline & Protestan & 190 & 70 \\
\hline & Islam & 15 & 5 \\
\hline & Marapu & 38 & 14 \\
\hline \multirow[t]{5}{*}{ Suku } & Sumba Timur & 201 & 74 \\
\hline & Sumba Tengah & 4 & 1 \\
\hline & Sumba Barat & 21 & 8 \\
\hline & Sumba Barat daya & 10 & 4 \\
\hline & Lain-Lain & 37 & 13 \\
\hline
\end{tabular}

Tabel 2. Hubungan Faktor Independen Terhadap Perilaku Seks Pranikah Remaja (n=273)

\begin{tabular}{|c|c|c|c|c|c|c|c|c|}
\hline \multirow{3}{*}{ Variabel } & \multicolumn{8}{|c|}{ Perilaku Seks Pranikah } \\
\hline & \multirow[t]{2}{*}{ Kategori } & \multicolumn{2}{|c|}{ Menyimpang } & \multicolumn{2}{|c|}{$\begin{array}{c}\text { Tidak } \\
\text { Menyimpang }\end{array}$} & \multicolumn{2}{|c|}{ Total } & \multirow[t]{2}{*}{ p-value } \\
\hline & & $\mathbf{n}$ & $\%$ & $\mathbf{n}$ & $\%$ & $\mathbf{n}$ & $\%$ & \\
\hline \multirow[t]{2}{*}{ Teknologi } & Negatif & 197 & 72 & 10 & 4 & 207 & 76 & \multirow{2}{*}{0,292} \\
\hline & Positif & 25 & 9 & 41 & 15 & 66 & 24 & \\
\hline Dukungan Sosial dan & Ada Dukungan & 45 & 16 & 20 & 7 & 65 & 23 & \multirow{2}{*}{0,004} \\
\hline Kekerabatan & Tidak Ada dukungan & 177 & 65 & 31 & 11 & 208 & 76 & \\
\hline \multirow[t]{2}{*}{ Nilai Budaya dan Gaya Hidup } & Tidak Mengikuti & 48 & 18 & 20 & 7 & 69 & 25 & \multirow{2}{*}{0,011} \\
\hline & Mengikuti & 173 & 63 & 31 & 12 & 204 & 75 & \\
\hline Kebijakan dan Peraturan Yang & Perlu & 211 & 77 & 49 & 18 & 260 & 95 & \multirow{2}{*}{0,775} \\
\hline Berlaku & Tidak Perlu & 11 & 4 & 2 & 1 & 13 & 5 & \\
\hline \multirow[t]{2}{*}{ Ekonomi } & Baik & 45 & 16 & 20 & 7 & 197 & 72 & \multirow{2}{*}{0,004} \\
\hline & Kurang & 177 & 65 & 31 & 11 & 76 & 28 & \\
\hline \multirow[t]{2}{*}{ Pengetahuan } & Cukup & 89 & 33 & 20 & 7 & 260 & 95 & \multirow{2}{*}{0,890} \\
\hline & Kurang & 132 & 48 & 31 & 11 & 13 & 5 & \\
\hline
\end{tabular}

dari 51 responden yang tidak berperilaku seks menyimpang terdapat 20 responden dengan pendidikan cukup dan 51 responden dengan pengetahuan kurang. Berdasarkan output di atas didapatkan nilai korelasi pearson chi-square sebesar 0.000 dengan nilai signifikansi sebesar $0.890>0.05$, maka dapat diambil kesimpulan bahwa tidak terdapat hubungan signifikan antara pengetahuan dengan perilaku seks pra nikah [Tabel 2].

\section{PEMBAHASAN}

Faktor teknologi tidak memiliki hubungan dengan perilaku seks pranikah remaja. Sebagian besar siswa/i tidak terpapar media memiliki resiko perilaku seks pranikah menyimpang dibandingkan dengan yang terpapar media informasi. Tidak adanya hubungan pemanfaatan teknologi dengan perilaku yang tinggal di desa dan dikota memiliki pertimbangan yang matang untuk melakukan perilaku seks menyimpang atau sebelum menikah (3). Pencegahan perilaku seksual beresiko dapat dilakukan dengan berbagai cara, tidak hanya dilakukan melalui media internet, karena remaja yang tinggal di desa tidak dapat dijangkau untuk kesetaraan perolehan informasi. Informasi-informasi penting yang dapat disampaikan misalnya infeksi menular seksual, sikap mengenai penggunaan kondom dan kemampuan atau kemauan diri terhadap penggunaan kondom yang konsisten (11). Bagi remaja diluar akses internet memadai atau di wilayah pedesaan penyebaran informasi dapat melalui pendekatan secara transcultural dengan masyarakat, dalam arti perawat komunitas dapat melakukan penyuluhan tentang perilaku seks pranikah melalui 
kegiatan-kegiatan masyarakat seperti adat prapernikahan dan adat istiadat lainnya atau melalui asuhan keperawatan keluarga.

Hasil penelitian pada variabel nilai budaya dan gaya hidup menunjukkan adanya hubungan yang signifikan $(p=0,011)$ terhadap perilaku seks pranikah remaja di Kabupaten Sumba Timur. Hasil penelitian ini sama dengan pernyataan (20) bahwa sosial budaya berpengaruh terhadap terbentuknya perilaku seseorang. Presentase remaja yang berperilaku seks pranikah menyimpang mayoritas memilih mengikuti budaya. 222 responden yang berperilaku seks pranikah menyimpang 173 menganggap biasa (mengikuti budaya) melakukan seks sebelum menikah karena tradisi perjodohan, dan dari 51 responden yang berperilaku seks pranikah tidak menyimpang hanya terdapat 20 responden yang tidak mengikuti budaya. Sesuai dengan penelitian (21) remaja yang mengikuti budaya cenderung akan melakukan perilaku seks pranikah. Faktor budaya yang paling mempengaruhi dalam penelitian ini terletak pada nilai-nilai dan norma yang ditanamkan turun temurun seperti tradisi perjodohan. Perkawinan ini dikenal dengan sistem perjodohan. Perkawinan dengan sistim perjodohan ini merupakan jenis perkawinan yang sengaja dikembangkan di Sumba Timur (19). Upaya menurunkan angka perilaku seks remaja yang sangat berhubungan erat dengan budaya dan gaya hidup di Kabupaten Sumba Timur dapat diatasi dengan melakukan pendekatan transcultural, yaitu PKPR dapat bekerja sama dengan pelaksana adat didaerah tersebut untuk sesering mungkin dilakukan penyuluhan, seperti penelitian (22).

Dukungan sosial dan kekerabatan berhubungan erat dengan perilaku seks pranikah remaja di Kabupaten Sumba Timur. Penelitian ini sesuai dengan penelitian (3) yang menyatakan bahwa ada hubungan antara kontrol orang tua dengan perilaku seks remaja. Sebagian besar remaja yang berperilaku seks pranikah menyimpang tidak mendapat dukungan sosial dan kekerabatan dari keluarga. Dari 273 responden diperoleh hasil sebanyak 177 (65\%) responden yang tidak memiliki support sosial dan kekerabatan. hal ini disebabkan karena rata-rata responden tidak tinggal serumah dengan orang tua mereka, melainkan tinggal dengan famili lain seperti nenek, paman/bibi, bahkan tinggal dengan kenalan dari orang tua yang tidak memiliki hubungan kekerabatan sama sekali dengan responden. Sebagian besar ibu yang hamil diusia remaja, mengaku kurang berkomunikasi dengan orang tua seputar masalah kesehatan reproduksi. Kebanyakan dari mereka tidak memiliki teman curhat di rumah dan memiliki perasaan kesepian serta ketidak pedulian dari orang tua. Beberapa hal inilah yang membuat mereka melakukan hubungan seks tanpa pengaman dan tanpa rasa takut (3). Orang tua pada umumnya memiliki pandangan yang negatif tentang seks dan pendidikan seksualitas untuk anak-anak mereka. Mereka merasa tabu membicarakan hal-hal seputar masalah seksual dengan anak-anaknya. Presepsi seperti ini harus dirubah, memahami bagaimana komunikasi bekerja dengan baik antara orang tua dan anak-anak sangat diperlukan untuk menghindari berbagai masalah seperti, kehamilan remaja, pernikahan dini, putus sekolah, dan masalah ekonomi bagi remaja yang hamil pada usia sekolah dan belum mampu secara finansial untuk membiayai diri sendiri dan keluarganya. Kesadaran akan pentingnya pengaruh keluarga akan membantu orang tua menekankan moral yang baik bagi anakanaknya,untuk menghindari hal-hal yang tidak diinginkan. (3)

Faktor kebijakan dan peraturan, tidak ada hubungan dengan perilaku seks pranikah remaja di Kabupaten Sumba Timur. Ini terlihat dari 222 responden yang berperilaku seks pra nikah menyimpang terdapat 211 responden tidak merasa perlu adanya dukungan kebijakan dan peraturan dan 11 responden yang memerlukan dukungan kebijakan dan peraturan. Sedangkan dari 51 responden yang menerima seks pra nikah terdapat 2 responden tidak memerlukan dukungan kebijakan dan peraturan dan 49 responden memerlukan adanya dukungan kebijakan dan peraturan. Hal ini tidak sesuai dengan teori Transcultural nursing yang menjelaskan bahwa kebijakan dan peraturan yang berlaku dan segala sesuatu akan mempengaruhi seseorang melakukan kegiatan atau perilaku individu. Lembaga yang turut bekerja sama menjalankan program kesehatan remaja adalah Lembaga Swadaya Masyarakat (LSM). LSM menjadi sebuah penggerak dan sebagai kekuatan yang berasal dari masyarakat, lebih dekat dengan masyarakat memiliki peranan yang besar dalam mensosialisasikan Undang-Undang perkawinan didaerah-daerah terpencil sebagai tugas pelayanan bagi masyarakat khususnya pelayanan kesehatan bagi remaja.

Faktor ekonomi menunjukkan sebagian besar remaja berperilaku seks menyimpang 177 diantaranya memiliki ekonomi yang baik dan 45 responden berasal dari keluarga dengan ekonomi rendah, dari 51 remaja dengan perilaku seks pranikah tidak menyimpang 20 remaja berasal dari keluarga dengan ekonomi baik dan 31 dari keluarga dengan ekonomi kurang. Hal ini sepadan dengan dengan penelitian (1). status ekonomi yang hidup dengan fasilitas berkecukupan akan udah mengakses tempat-tempat yang memungkinkan adanya kesempatan melakukan seks pranikah dan sebaliknya remaja dengan ekonomi rendah memiliki banyak kebutuhan yang harus dipenuhi, sehingga cenderung mencari kesempatan untuk memanfaatkan dorongan seksnya demi mencukupi kebutuhannya. Sesuai dengan penelitian (23) remaja dengan ekonomi tinggi maupun rendah keduanya memiliki resiko untuk melakukan perilaku seks pranikah oleh karena itu diperlukan upaya pencegahan agar tidak terjadi dampak pada kehamilan yang tidak diinginkan, infeksi menular seksual maupun berbagai dampak lain. Hal ini dapat dilakukan dengan meningkatkan pendidikan kesehatan remaja yang diberikan secara 
menyeluruh baik kepada remaja dengan ekonomi baik maupun kurang baik.

Tidak ada hubungan antara faktor pendidikan/pengetahuan dengan perilaku seks pranikah remaja di Kabupaten Sumba Timur, 222 responden yang memiliki perilaku seks pranikah menyimpang, 132 diantaranya adalah dengan pendidikan yang kurang tentang perilaku seks pranikah. Hal ini bertentangan dengan penelitian bahwa semakin baik pengetahuan seseorang remaja semakin rendah perilaku buruknya. Sebagian besar remaja memiliki pengetahuan hanya sebatas ciri-ciri fisik perkembangan seksualitas dan dampak perilaku seks pranikah. Akan tetapi masih ada remaja yang belum memahami bentuk dari perilaku seks pranikah. Hal ini disebabkan karena kurangnya pendidikan tentang perilaku seks di rumah dan di sekolah. Dalam permasalahan ini tampak dengan jelas, bahwa bentuk implementasi program pelayanan kesehatan yang juga adalah dukungan pemerintah terhadap pertumbuhan dan perkembangan remaja dalam bentuk Pelayanan Kesehatan Peduli Remaja (PKPR) belum berjalan dengan baik, terbukti bahwa banyak remaja yang tidak menerima penyuluhan tentang kesehatan reproduksi dan pemantauan kesehatan dari Puskesmas atau perawat komunitas yang mengelola Program (PKPR) di Sekolah. Selain kurang aktifnya perawat komunitas (pengelola PKPR) jumlah kunjungan petugas kesehatan disekolah sangat terbatas yaitu hanya dilakukan 1 kali dalam 1 tahun yaitu pada saat tahun ajaran baru dimuliai dan hanya dikhususkan untuk siswa/i baru (15).

Sumba Timur dengan adat dan budaya pernikahan yang menganut perkawinan satu arah atau eksogami. Model pernikahan yang berlaku perjodohan antara anak laki-laki dari garis ibu dijodohkan dengan anak perempuan dari garis bapak. Anak tidak langsung dinikahkan, tapi diikat secara adat oleh kedua keluarga besar sebagai tanda sahnya perjodohan (6). Rata-rata remaja yang melakukan perilaku seks pranikah adalah yang dijodohkan, selain merasa sudah sah secara adat, ada juga yang tidak setuju dengan perjodohan tersebut dan melakukan perilaku seks pranikah dengan laki-laki yang dicintainya dan melakukan perkawinan lari (7). Transcultural nursing, menjelaskan ada beberapa aspek kehidupan yang dapat menyebabkan manusia berperilaku, seperti perbedaan nilai-nilai budaya, suku, religious, sosial, ekonomi, pendidikan dan demografi (24). Remaja perlu menjaga perilaku seksual secara sehat adalah karena dalam perkembangannya, belum memahami tentang dampak perilaku seksual yang beresiko, apalagi rasa keingintahuan remaja mengenai seksual tinggi (25).

\section{KESIMPULAN}

Dukungan sosial dan kekerabatan, nilai budaya dan gaya hidup serta faktor ekonomi sangat berhubungan erat dengan perilaku seks pranikah remaja di Kabupaten Sumba Timur. Adanya keinginian untuk meningkatkan taraf kehidupan sosial dan menjaga martabat keluarga menjadi salah satu alasan remaja melakukan perilaku seks pranikah remaja, remaja yang dijodohkan merasa perlu mempertahankan derajat dan kekerabatan, dan menganggap melakukan hubungan seks sebelum menikah dengan pasangan yang dijodohkan adalah hal yang wajar. Demikian halnya dengan nilai budaya dan ekonomi, rata-rata remaja yang melakukan perilaku seks sebelum menikah adalah remaja yang sangat mendukung budaya perjodohan, selain untuk memertahankan derajat dan martabat keluarga, perjodohan dan perilaku seks pranikah dianggap biasa juga untuk memperbaiki perekonmian keluarga.

Pemanfaatan teknologi tidak serta merta menjadikan remaja di Kabupaten Sumba Timur berpotensi melakukan perilaku seks pranikah menyimpang. Pengaruh terbesar ada pada faktor dukungan sosial dan kekerabatan, Nilai budaya dan gaya hidup serta faktor ekonomi menjadi hal yang sangat mempengaruhi perilaku seks remaja. Faktor tidak tinggal dengan orang tua, dan untuk memperbaiki ekonomi keluarga membuat remaja dengan mudah melakukan hubungan seks sebelum menikah. Demikian halnya dengan faktor pengetahuan, remaja yang memiliki pengetahuan baik tentang pendidikan seks tidak berarti remaja tersebut tidak berperilaku seks pranikah. Remaja yang tinggal di Kabupaten Sumba Timur dan berasal dari Suku Sumba berpotensi memiliki perilaku seks pranikah remaja dibandingkan dengan yang bukan berasal dari Sumba karena banyak remaja masih memiliki pemikiran bahwa melakukan hubungan seks sebelum menikah dengan orang yang dijodohkan dapat mempertahankan strata atau status sosial.

Penelitian berikutnya hendaknya bisa mengembangkan penelitiannya, dengan melakukan penelitian secara kualitatif untuk dengan lebih jelas mendengar alasan melakukan perilaku seks pranikah dan melakukan penelitian kepada stakeholder remaja dalam kaitannya dengan implementasi Program Pelayanan Kesehatan Peduli Remaja (PKPR).

\section{UCAPAN TERIMA KASIH}

Kami mengucapkan terima kasih kepada Kepala SMA N 1 Lewa dan SMA N 1 Nggaha Ori Angu untuk izin dan penerimaan kami untuk melakukan pengambilan data sebagai bahan penelitian dan bagi semua siswa/i untuk kesediaan menjadi responden.

\section{DAFTAR PUSTAKA}

1. Luh N, Arsani KA, Nyoman N, Agustini M, Ketut I, Purnomo I, et al. Peranan Program PKPR (Pelayanan Kesehatan Peduli Remaja Terhadap Kesehatan Reproduksi Remaja di Kecamatan Buleleng. J Ilmu Sos dan Hum. 2013;2(1):2303898.

2. Yanikkerem E, Yasayan A. Vaginal douching 
practice: Frequency, associated factors and relationship with vulvovaginal symptoms. J Pak Med Assoc. 2016;66(4):387-92.

3. Sámano R, Martínez-Rojano $\mathrm{H}$, Robichaux $\mathrm{D}$, Rodríguez-Ventura AL, Sánchez-Jiménez B, de la Luz Hoyuela $M$, et al. Family context and individual situation of teens before, during and after pregnancy in Mexico City. BMC Pregnancy Childbirth. 2017 Dec;17(1):382.

4. O'Carroll T. Childhood 'Innocence' is Not Ideal: Virtue Ethics and Child-Adult Sex. Sex Cult. 2018 Apr;1-33.

5. Sryoputro A, Ford NJ, Shaluhiyah Z. FaktorFaktor Yang Mempengaruhi Perilaku Seksual Dan Layanan Kesehatan Seksual Dan Reproduksi. Mkara, Kesehat. 2006;10(1):29-40.

6. Kleden D. Perkawinan Adat Sumba. study Budaya Nusant. 2017;1:64-5.

7. Sulistyawati Y, Putu N. Perkawinan Lari, Pakodong. Kesmas Natl Public Heal J.

8. Leininger MM, McFarland M. Transcultural Nurshing: Concept, Teories, research and practice. New York: McGraw-Hill. 2002;

9. Triningsih RW, Widjanarko B, Istiarti VGT. Faktor-faktor yang Berpengaruh terhadap Praktik Seks Pranikah pada Remaja di SMA Dekat Lokalisasi di Wilayah Kabupaten Malang. 2015;10(2).

10. Li G, Hines M. In Search of Emerging Same-Sex Sexuality: Romantic Attractions at Age 13 Years. Arch Sex Behav. 2016 0ct;45(7):1839-49.

11. Doubova S V., Infante-Castañeda C, Pérez-Cuevas $\mathrm{R}$. Internet-based educational intervention to prevent risky sexual behaviors in Mexican adolescents: study protocol. BMC Public Health. 2016 Dec;16(1):343.

12. Fadlyana E, Larasaty S. Pernikahan Usia Dini dan Permasalahannya. Sari Pediatr. 2016;11(2):136.

13. Noonan M, Lecturer RGN, Doody O, Lecturer R, Jomeen J, Galvin R. Midwives ' perceptions and experiences of caring for women who experience perinatal mental health problems : An integrative review. Midwifery. 2017;45(April 2016):56-71.

14. Yunitasari E, Pradanie R, Susilawati A. Kecamatan Torjun Sampang Madura ( Early
Marriage Based on Transcultural Nursing Theory in Kara Village Sampang ). 2016;(2015).

15. Ministry of Health Republic of Indonesia. Pedoman Standar Nasional Pelayanan Kesehatan Peduli Remaja (PKPR) [Guidance of national standard of adolescent health services]. 2014. 1 p.

16. Garcimartin P, Comin-Colet J, Delgado-Hito P, Badosa-Marcé N, Linas-Alonso A. Transcultural adaptation and validation of the patient empowerment in long-term conditions questionnaire. BMC Health Serv Res. 2017 Dec;17(1):324.

17. Karaku Z, Student M. Nurses ' Views Related to Transcultural Nursing in Turkey. 2013;6(2):201-7.

18. Untari AD. Skripsi analisis faktor yang berhubungan dengan perilaku seks pranikah pada remaja yang tinggal di wilayah eks lokalisasi berdasarkan teori. 2017;

19. Anggraeni. Pergesar Makna Belis Dalam Adat Perkawinan Masyarakat Sumba. Artik Progr Stud Pendidik. 2003;74-88.

20. Notoadmodjo S. Promosi Kesehatan dan Perilaku Kesehatan. Jakarta: Rineka Cipta; 2012.

21. Umaroh AK, Kusumawati Y, Kasjono HS. Hubungan Antara Faktor Internal Dan Faktor Eksternal Dengan Perilaku Seksual Pranikah Remaja Di Indonesia. 2015;65-75.

22. Mbulur FN, Hary TP. Sikap Remaja Terhadap Kepercayaan Marapu Di Kabupaten Sumba Timur Nusa Tenggara Timur. J Spirits. 2013;3(2):1-92.

23. Shoemaker KK. Early Adolescent Perceptions Regarding Sources Of Sexual Health Information. 2017;

24. Leininger M. Culture Care Theor : A Ma or contri ution to Advance Transcultural ur sing Knowladge and Practies. J Transcult. 2002;13:189.

25. Lampkin DP. The Girl Factor: How Single-Sex Learning Environments Affect African American Girls ' Discipline Referral Rate by A Dissertation Presented in Partial Fulfillment of the Requirements for the Degree Doctor of Education Liberty University. 2016; 